\title{
SYMPATHETIC NERVOUS FUNCTION IN VERTIGINOUS PATIENTS
}

\author{
JUN-ICHI YOSHIDA, M. D
}

Department of Otolaryngology, Osaka University Medical School, Osaka

Plasma levels of norepinephrine (NE), which are useful index of sympathetic nervous function, were measured in vertiginous patients by gas chromatograph-mass spectrometer using selected ion monitoring method.

There was no significant difference in the resting plasma NE levels between healthy subjects and patients groups such as Meniere's disease, vertigo (central and peripheral origin) and sudden deafness.

$\mathrm{XE}$ and blood pressure increased in all groups when the subjects were kept at the standing errect position. No significant differences were found in the increment of $\mathrm{NE}$ at the errect position, however, there was less elevation in blood pressure in patients groups, especially in Meniere's disease patients.

Lsing another patients group of subjecus such as Meniere's disease and sudden deafness patients, pressor response for intravenously administered NE was studied. Meniere's disease patients showed hyporesponsiveness of blood pressure to exogenously administered NE.

These facts suggest that sympathetic effector organs in Meniere's disease patients are functionally disturbed.

A86-0421-90842

\section{めまい患者の自律神経機能}

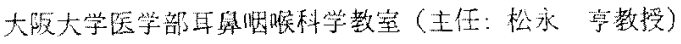 \\ 吉田幥一
}

\section{Iはじめに}

メニエール病は病理組織学的には内リンバ水腄に由来 するむのと考えられている方，专の発生機序については いまだ不朋の点が多い，徉来上りをの成因に関して，丁

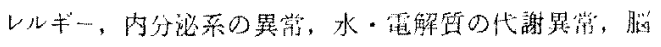

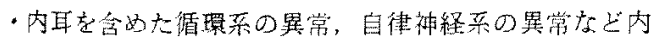
的因子と，各種ストレスの外的因子拉上び局所解剖学的 な異常などの局所因子が互いに作用し，めまいが発現す

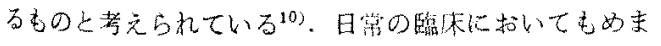
い患者ことにメニエール病患者に执いて，低血压煩问， 起立性調節障害などの循環采の翼常がしばしば見られる

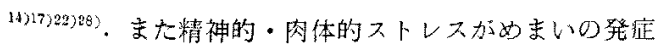

に大きく関倸している挒もしばしば琶められる。これら 循㻴茅の異常、ストレスの関与などの根底には自律神経 系の異常が存在することを示盯ものとして注目され，め 末い発症の原因をさぐる系口として，現在亲でこの而仙

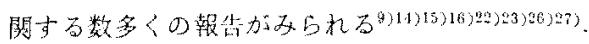

自律神経亲の機能検查法には数多くの方法が試みられ ている．血中力テコーラミン(CA) は測定法の確立とと もに，交感神経系の有力指摽として，近等各形の疾患

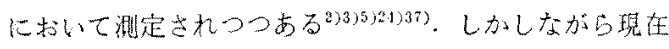
まで Gejrot ら のメニエール病に批ける尿中 CA の 報告を除いて，めまい患者に拉けるCA の動態の報告

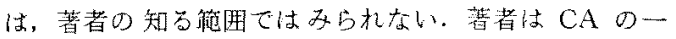




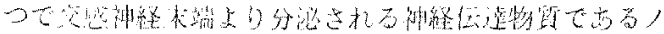

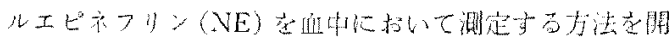

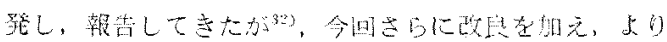

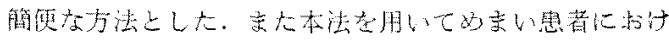

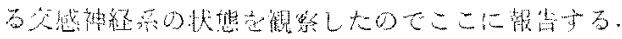

\section{II 血中ノルエピネフリンの定量}

A）方法

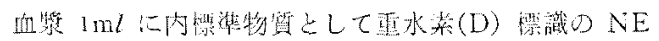
$\alpha \mathrm{D}_{\beta} \mathrm{D}_{1}(\mathrm{D}-\mathrm{NE})$ long $(20 \mathrm{ng} / \mathrm{m} l \quad 0.01 \mathrm{NHCl})$ 和小心

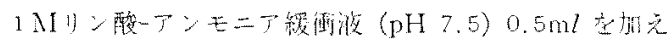

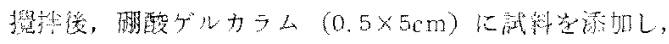

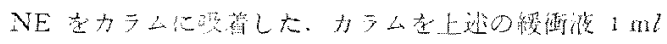

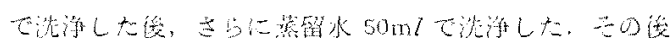

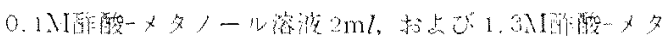

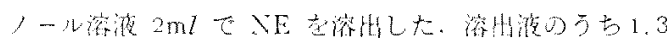

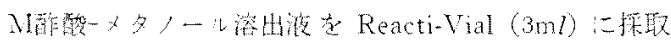

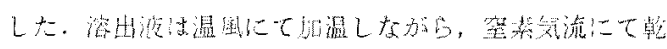

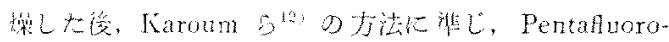

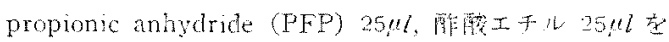

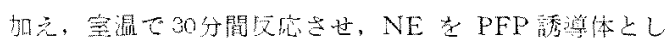

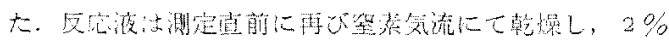

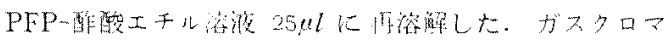

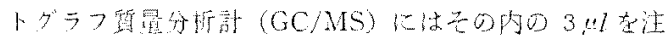

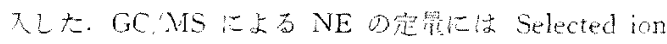

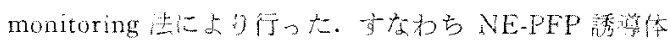

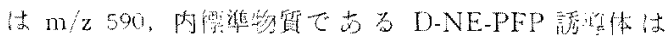

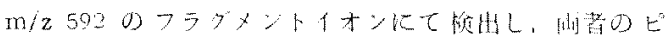
一名高此化定鼠した。

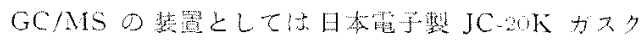

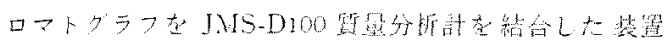

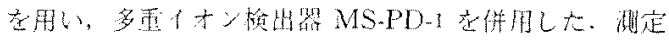
条件は以下の涌りて方分。

ガスクロマトグラフ(GC) のカラムには $3 \mathrm{~mm} \times 2 \mathrm{~m}$

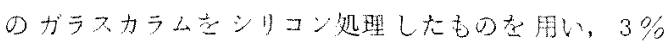
OY-1/Gas Chrom Q (100-200 mesh) t充填Lた。 力

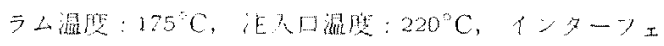

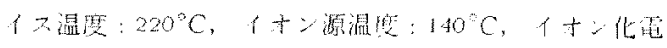

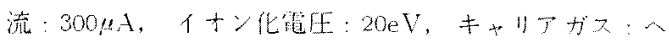
リウム、生 $1.8 \mathrm{~kg} / \mathrm{cm}^{2}$ とした。

㽗酸ゲの活性化は以下の整邻で行った。研酸ゲル

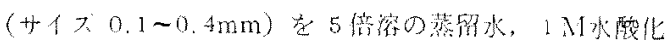

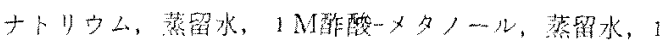

Mアンモ二ア水の順に各5国らつ洗海した，さらに蒸

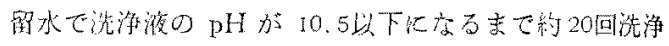
した.

B）結果拉よび考揬

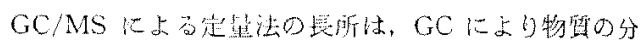

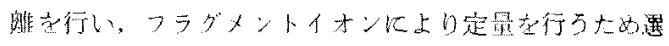

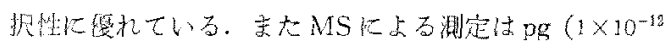
g) 当位の高感隻で方り, さらに内慓集物筫上しては理

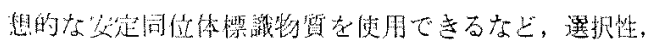

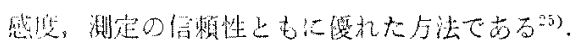

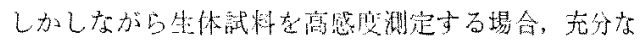

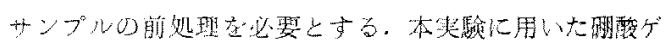

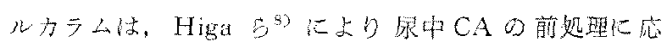
朋されたもので，促来のアルミ吸符法上此顿して，大

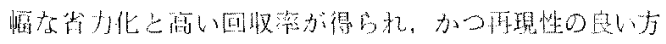
法である。しかしながら頪酸ゲルカラム志 GC/MS 測

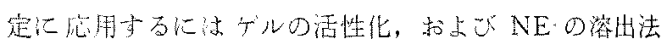
に2，30工走必要とした。ゲルの活性化は1 M酸酸メタノ一儿溶源で流游したが，この過程は，ゲル上り溶 出し、クロマトグラム上江出現する末知のピーク学減少

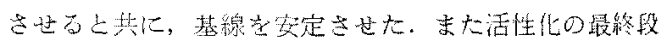

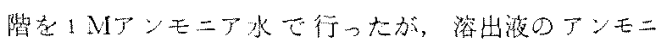

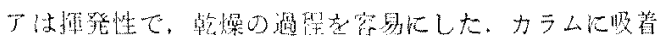

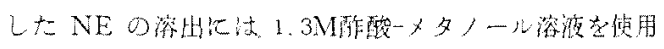

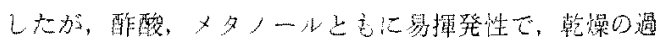

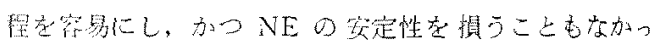
太.

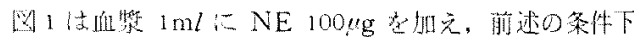

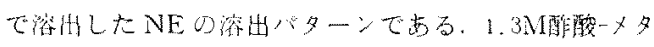
ノ一儿淮苳の银初の $2 \mathrm{ml}$ に的 $90 \%$ の NE が溶出与る。 $3 \mathrm{~m} l$ 志で採职古古上 $100 \%$ 回收でるが、D-NE在内

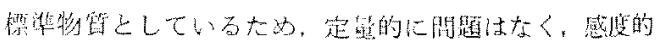
に屯充分であるので $2 \mathrm{~m} l$ 採取した。

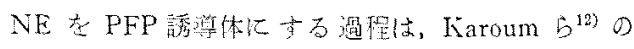

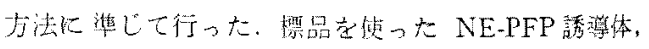

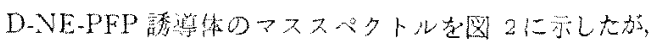
Karoun らの結坚上ほ添一致した。

NE，D-NEの旗圠《は，基本ビークである $\mathrm{m} / 2176$, 128 が感度上有利で节るが、ク口マトグラムの想線の安

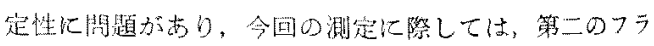

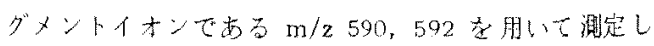
た.

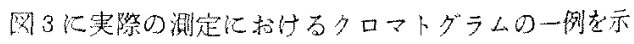




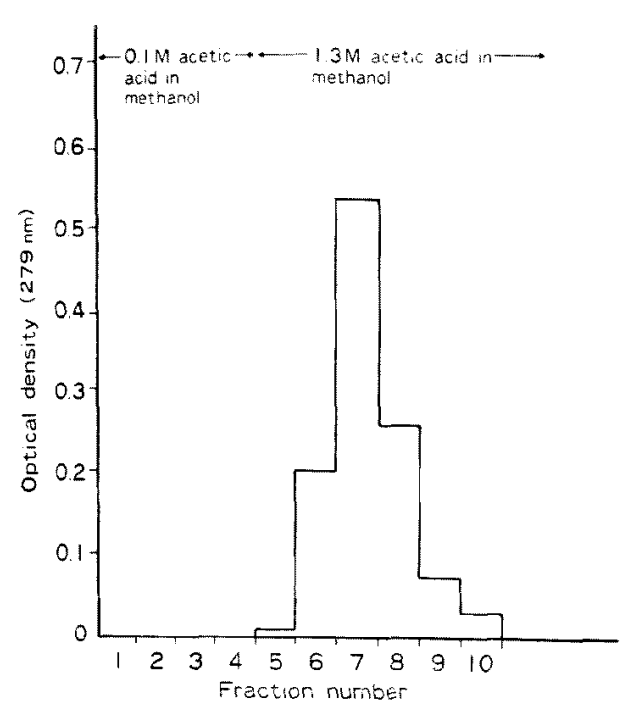

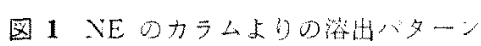
フラクション+イズ $0.5 \mathrm{~m}$
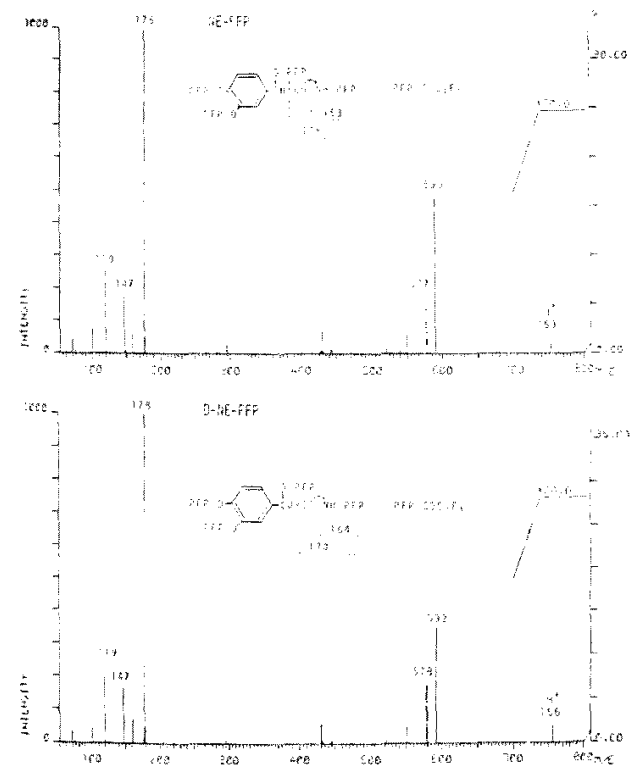

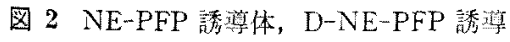
体のマススハタトル

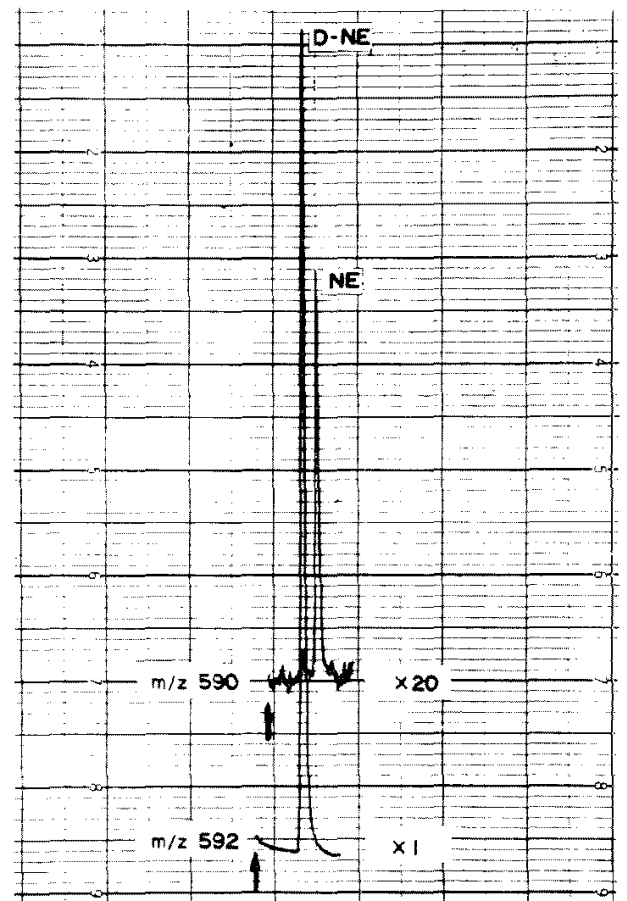

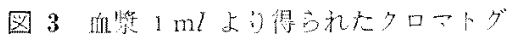
$\Rightarrow \angle$. NE $180 \mathrm{pg} / \mathrm{ml}$

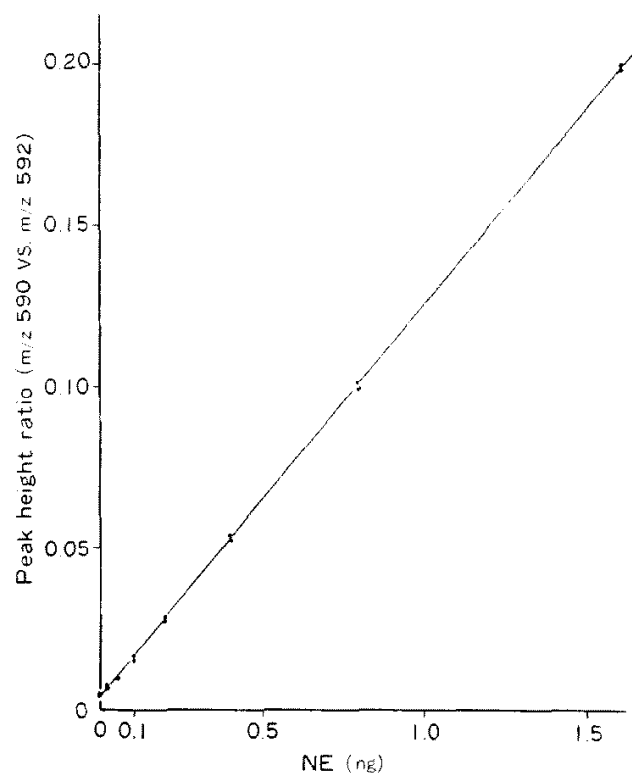

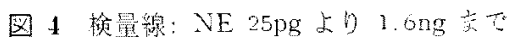

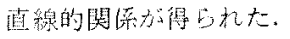


した，图に示索ごをく，安定した基線上にNEのピー クがみられた。

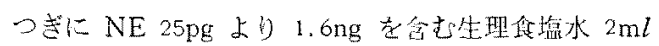
に $10 \mathrm{ng}$ の D.NE 加光，前述の实駼条件下で湘定を 行い检量線さ作整した，图4に示したようにNE $25 \mathrm{pg}$

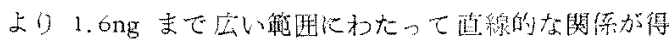
ら机た。

また本測定法の再現性に関して，同一の血獎 5 検体を

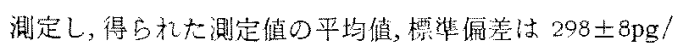
$\mathrm{m} l$ であり，非常に良い再現性を示した。

\section{III めまい患者における血中 NE の動態}

メニエール病を仙しとするめまい患者に呫ける血中

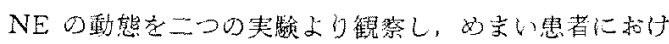
る交感神経采の状想を謂心た。

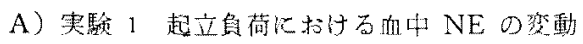

本奏験ては安静洔特よび交感神経刺激（起立負荷）时 の血中 NE の变動を調へた。

1) 対象

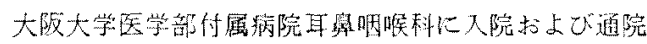
中の患者 70 名, 践康成人 10 名, 計 80 名を対象亡した。 乞の内訳, 年龄, 性別恃表1儿示したごとく、非活動期

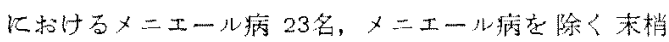

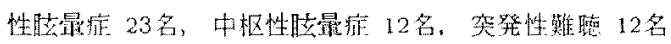
である。な机こ机占の㭧者には検查前 1 週間は投薬は行 わなかった。対照上した健康成人には全身的に異常な く，過去にめまい，立ちくらみなど，め宗いに関倸した

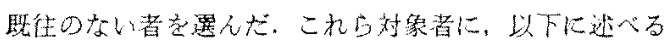
ことく，㚣静時㧍よび起立的荷時の血中 NE 老溉定する とともに，古わせて全身反応の指標となる血在との関保 龙好大。

\section{2）採血㧍よび起立目荷の方法}

梚查は午後 2 時上り4 時までの間で行った，採血は前 腕の静脈よりへバリン血として採取した，採血に際して

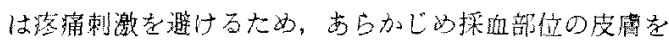

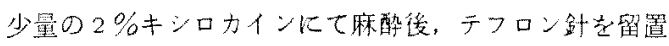
し、テフロン針に接続した三方活䖽より採血した，血圧 の测定には，自動血圧計（日本コーリン BP 103）を使 用し，採血と反対側の上腕で測定した，テフロン倽を留 置後, 15 分閏の卧位安静ののb, 血生, 脈拍の安定した こ上老確認し，安静時の血液を探取し，阔時儿血㞋，眽

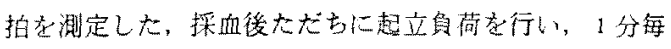
に血王，脈拍を測定しながら，起立負荷 5 分㣦, 10 分後

\begin{tabular}{|c|c|c|c|}
\hline & 例数 & $\begin{array}{l}\text { 性別 } \\
\text { 男: 女 }\end{array}$ & 年齢 \\
\hline$x=I-ル$ 病 & 23 & $14: 9$ & $42(23-61)$ \\
\hline 末梢性垷孀症 & 23 & $10: 13$ & $45(20-66)$ \\
\hline 中殹性䏠星症 & 12 & $6: 6$ & $56(29-69)$ \\
\hline 乫発性獾聴 & 12 & $8: 4$ & $36(19-49)$ \\
\hline 健康成人 & 10 & $5: 5$ & $28(19-43)$ \\
\hline
\end{tabular}

表 2 安静時血中 $N E$ 值，平均䧿脱死

\begin{tabular}{|c|c|c|}
\hline & $\begin{array}{c}\text { 血中 } \mathrm{NE} \text { 値 } \\
(\mathrm{ng} / \mathrm{m} l)\end{array}$ & $\begin{array}{l}\text { 平均動脤压 } \\
(\mathrm{mmHg})\end{array}$ \\
\hline$x=エ ー ル$ 病 & $0.24 \pm 0.098$ & $81.6 \pm 12.2$ \\
\hline 末梢性䏠最症 & $0.25 \pm 0.12$ & $88.3 \pm 11.2$ \\
\hline 中枢性眹最症 & $0.32 \pm 0.13$ & $88.4 \pm 11.8$ \\
\hline 突発性觀愳 & $0.23 \pm 0.086$ & $86.9 \pm 12.4$ \\
\hline 健康成人 & $0.26 \pm 0.089$ & $83.8 \pm 10.0$ \\
\hline
\end{tabular}

飞採血を行った。得られた血液は $4^{\circ} \mathrm{C} 3000 \mathrm{rpm}$ で 10

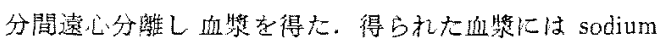
metabisulfitc $(0.5 \mathrm{mg} / \mathrm{m} l)$ を丵加し，測定まで $-20^{\circ} \mathrm{C}$ で冷谏保存した。

3) 結果

a）安静時血中 $N E$ 値, 血E

メ二エール病，末梢性睹最症，中枢性脑㫤症，突発性 嚾㯖叔上び健康成人口安静時血中 NE 值, 血王（平均動 眽王）を表2 亿示した，安静時に括ける血中 NE 值の平 均士標準偏差佉入二エール病 $0.24 \pm 0.098(\mathrm{ng} / \mathrm{ml}$ 以 下单位省略), 未梢性矓最定 $0.25 \pm 0.12$, 中枢性眩晕症 $03 . \pm 0.13$, 乫発性難噜 $0.23 \pm 0.086$ であり，中枢性矓 最症にや和高い㑯向がみら礼たが，健康成人 $0.24 \pm$

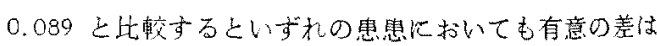
みられな加った。 ( $\mathrm{p}>0.1)$

また安静時の平均動脈在はメ二エール病 $81.6 \pm 12.2$ ( $\mathrm{mmHg}$ 以下単位省略)，末梢性胿最症 $88.3 \pm 11.2$, 中 枢性眩最症 $88.4 \pm 11.8$ ，突発性奞婹 $86.9 \pm 12.4$ 七市 り疾患群の中ではメニエール病に抋いて低血性倾向が

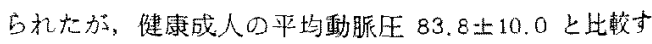
るといずれの族思沈招いても有意の差はみら礼なっ た. $(p>0.1)$

b) 起立負荷時の血中 NE 值, 血王の变到 
表 3 起立目荷時の血中ノルエピネフリン值 血圧

\begin{tabular}{|c|c|c|c|c|}
\hline & \multicolumn{2}{|c|}{ 血中 NE 值 $(\mathrm{ng} / \mathrm{m} l)$} & \multicolumn{2}{|c|}{ 平均勘脤压 (mmHg) } \\
\hline$x=エ ー ル$ 病 & $0.43 \pm 0.16$ & $0.46 \pm 0.16$ & $88.3 \pm 14.3$ & $89.3 \pm 16.5$ \\
\hline 交梢性胘需症 & $0.45 \pm 0.22$ & $0.46 \pm 0.22$ & $98.1 \pm 14.4$ & $97.1 \pm 13.6$ \\
\hline 怄性此算症 & $0.52 \pm 0.18$ & $0.57 \pm 0.26$ & $95.3 \pm 13.7$ & $92.3 \pm 19.9$ \\
\hline 突発性難聴 & $0.40 \pm 0.17$ & $0.43 \pm 0.18$ & $93.9 \pm 21.5$ & $98.6 \pm 18.8$ \\
\hline 硉康晠人 & $0.42 \pm 0.10$ & $0.47 \pm 0.073$ & $101.0 \pm 14.9$ & $97.6 \pm 15.9$ \\
\hline
\end{tabular}

mean $\pm S D$

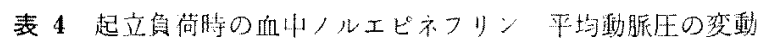

\begin{tabular}{|c|c|c|c|c|}
\hline & \multicolumn{2}{|c|}{$\begin{array}{c}\underset{1}{1} \text { 中 } \\
\text { 分 }\end{array}$} & \multicolumn{2}{|c|}{ 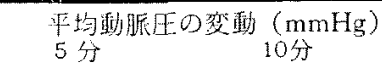 } \\
\hline$x=エ ー ル$ 病 & $0.20 \pm 0.096$ & $0.21 \pm 0.099$ & $6.7 \pm 6.9^{* * *}$ & $7.0 \pm 9.9^{*}$ \\
\hline 本梢性矓舅症 & $0.19 \pm 0.13$ & $0.20 \pm 0.12$ & $9.8 \pm 10.7^{*}$ & $8.2 \pm 8.4$ \\
\hline 中枢性胘鼠症 & $0.20 \pm 0.11$ & $0.25 \pm 0.16$ & $7.4 \pm 7.0^{* *}$ & $7.3 \pm 8.7$ \\
\hline 乫発性難㯖 & $0.17 \pm 0.10$ & $0.20 \pm 0.10$ & $7.0 \pm 13.3^{*}$ & $11.1 \pm 10.8$ \\
\hline 健康成人 & $0.16 \pm 0.043$ & $0.21 \pm 0.033$ & $17.1 \pm 8.6$ & $13.8+11.4$ \\
\hline
\end{tabular}

\begin{tabular}{ll} 
& \multicolumn{2}{c}{ mean $\neq S D$} \\
${ }_{p}<0.1$ & $* * p<0.01 \quad * * * p<0.001$
\end{tabular}

起立負荷 5 分拈よび10分に拉ける血中NE值，平均動

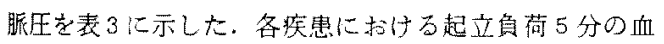
中 NE值は， メ二エール病 $0.43 \pm 0.16$, 末梢性垷斟症 $0.45 \pm 0.22$, 中枢性眹显症 $0.52 \pm 0.18$, 㔖発性蜼聴 $0.40 \pm 0.17$, 健康成人 $0.42 \pm 0.10$ です。．ま大起立

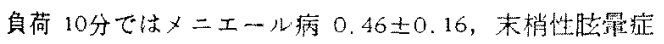
$0.46 \pm 0.22$, 中枢性妵星症 $0.57 \pm 0.26$, 突発性難聴

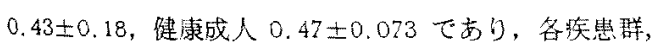
健康成人上も起立負荷時血中 NE 做は安静的七比校して 有意の上祭示した，

一方, 起立真荷 5 分における平均動脈圧は, メ二エー

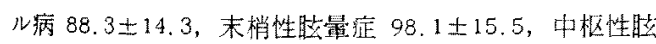
露症 $95.3 \pm 13.7$, 乫発性雉婹 $93.9 \pm 21.5$, 健康成人 $101 \pm 14.9$ ですった。起立負茼10分では，メ二工 一儿病 $89.3 \pm 16.5$, 未梢性胘罪症 $97.1 \pm 13.6$, 中枢性

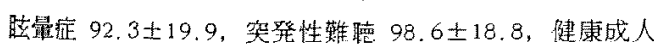
$97.6 \pm 15.9$ であり，各聅患群，健康成人之屯起立負荷 時の血任は安静時に比校して有意の上罪走した。

以上のごとく，起立負荷により血中 $\mathrm{NE}$, 血压ともに 有意の增加を認めたが，その際の血中NEおよび平均動 娦玨の変化分（それそれ $4 \mathrm{NE} ， \triangle \mathrm{MAP}$ と路す）につ

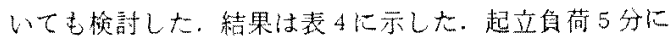

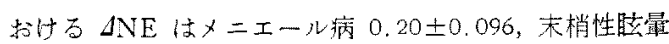

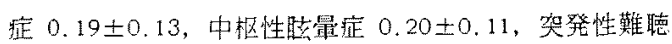
$0.17 \pm 0.10$ ，健康成人 $0.16 \pm 0.043$ であった。また起 立負荷10分ては，メ二エ一儿病 $0.21 \pm 0.099$, 末梢性渎 最症 $0.20 \pm 0.12$, 中枢性胠最症 $0.25 \pm 0.16$, 突発性嚾 聴 $0.20 \pm 0.10$, 健承成人 $0.21 \pm 0.033$ であり, 起立負

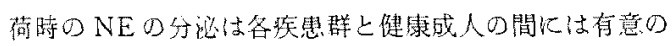

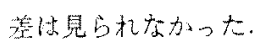

一方, 起立負荷 5 分に和りる $A \mathrm{MAP}$ はメ二エ一儿病 $6.7 \pm 6.9$, 未梢性敗最症 $9.8 \pm 10.7$, 中枢性矓最症 7.4 \pm 7.0 , 突器性難㯖 $7.0 \pm 13.3$ てあり, この值は健线成

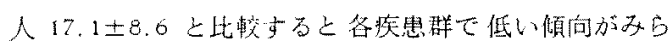
れたが，七くにメ二エール病 $(\mathrm{p}<0.001)$ ，中枢坐脑星 症 $(\mathrm{p}<0.01)$ では有暨に低い值であった。市た起文角 荷 10分における DMAP は，メ二エール病 7.0土9.9,

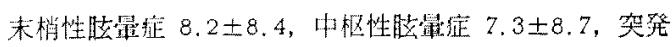
性難聴 $11.1 \pm 10.8$ でり, 健康成人 $13.8 \pm 11.4$ 上比 較すると各疾患群て低い值を示したが,メ二エール病に 执いてのみ低い傾问がみられた.（ $\mathrm{p}<0.1 ）$

背上のごとく，今回対象としためまい疾费においては 


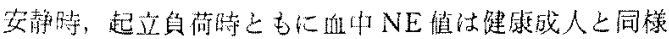
に分必されていた。しかしなが起立負荷時の血厓の上 年は健康成人の血圧の上昇に比較して低い上昇しかみら 机㳊加った。

\section{B）実䮲 2}

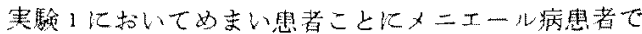
は内因性江分泌された NEの血圧八の反応性が低い点が 明ら吕汇なった．本実騟ではNEを静注した際の血圧一 の反忘性がめまい堭者で低下しているか否かを蚞討し た.

1)对象ならびに方法

対象にはメニエール病患者 10 名（男性4名，女性6 名), 突発性難聽 5 名 (男性 1 名, 女性 4名), 趾隶成人 6名（男性 4名，女性2名）を用いた。

NEの静注は卧位にて行った。 まつ被験者の一側前腕 KNE注入用のカテーテルを挿入し NE注入まで5\%キ シリトール溶液を 1 時間当たり $30 \mathrm{~m} l$ の速度で注入し た。他側の前腕には血液採取用の静脈力テーテルを实駼 1 の要領で留置した。血化の測定は血液採取側の上㴔に て1分每に测定した。

上記の操作終了後約15分間安静の後, 血圧, 脈拍の安 定したのを確認し，注入前の血液を採取した，之の復 $\mathrm{NE}$ (L・ノルエピネフリンを $5 \%$ キシリトール溶液で $5 \mu \mathrm{g} / \mathrm{m} l$ 江溶解）を 1 分閪 $2.5 \mu \mathrm{g}$ ○速度で注入を開始 した．10分俊江血液を採取した後，注入量を $5 \mu \mathrm{g} /$ 分に 增量した，以後同様に $10 ， 15 ， 20 \mu \mathrm{g} /$ 分に增量した。 な挂注入にはアトム自動輸液ポンプ R-100を使用した。

注入は以下の場合中止した。すな和ち 1）収維期圧が $40 \mathrm{mmHg}$ 以上上舁，2）抬張期圧吕 $30 \mathrm{mmHg}$ 以上上 昇，3）服拍減少が $30 /$ 分以上，である。

3) 結果

NE の注入K上り血在は上昇する。健康成人。名の血

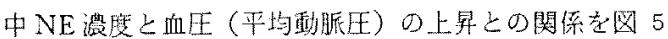

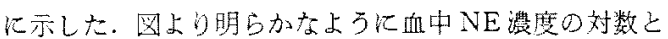
血王の上昇との間化蛙有意の相関関係が みら机た。（ $\mathrm{r}$

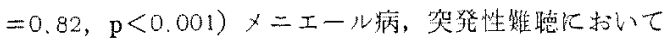
屯同様の関係が好られた。（それぞ机 $\mathrm{r}=0.70 \mathrm{p}<0.001$ ， $\mathrm{r}=0.62, \mathrm{p}<0.02)$

ここで直線の勾配をNEの血生への反応性，㨁線が平

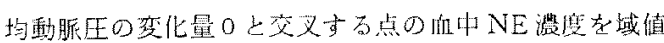

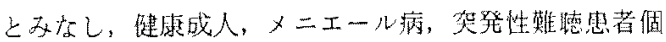
々に括いて計算すると, 健捸成人では反応性 $45.1 \pm 14.8$ 域值 $540 \pm 256 \mathrm{pg} / \mathrm{ml}, x=$ エール病では反応性 $30.0 \pm$

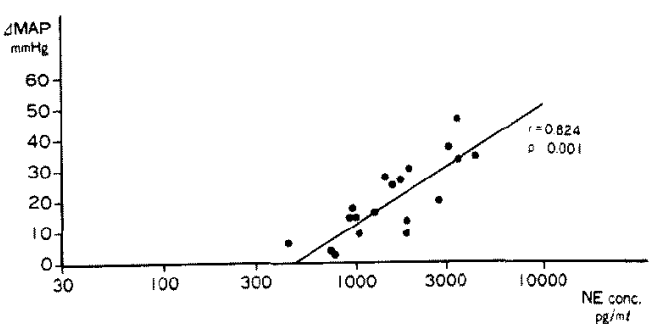

图5ノルエピネフリン静注時におけるノ ルエピネフリン濃度と平均動胀国の 变動との関倸

10.6 , 域值 $584 \pm 231 \mathrm{pg} / \mathrm{ml}$ ，突発性難㴔では度応性 $43.2 \pm 23.6$, 域值 $479 \pm 269 \mathrm{pg} / \mathrm{ml}$ となり, 域值汇括い ては差は見られなかったが，反応性に拁いて， ニエー 儿病は健康成人に比較して有意江低い值を示した（ $\mathrm{p}<$ $0.05)$

\section{IV 臨床成䜌の考按}

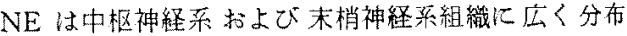
し, 神経興政江伴い放出される神経伝達物質として知占

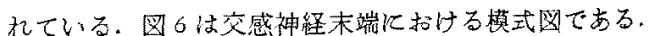

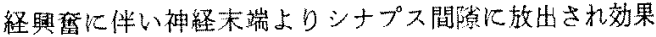

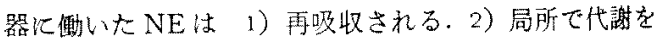
うける。３）一部は血中に放出される。したがって血中

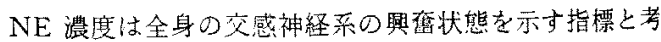
えられている。血中NEのレベルは神経本端からの NE

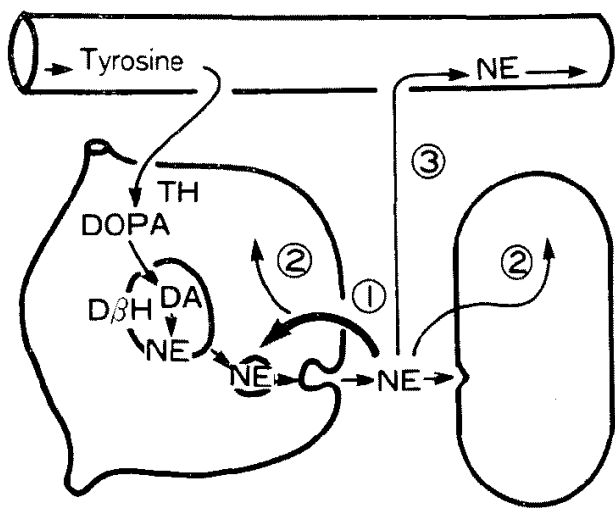

Adrenergic Axon Effector Cell Terminal

図 6 交感神释术端仙招讨る模式図 (Cryer ${ }^{3)}$ より引用) 


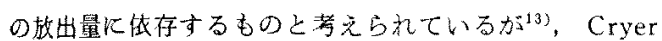
$5^{3)}$ が指摘するごとくシナブス内の NEの一部が放山さ

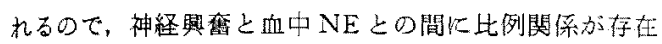
するかが閏題となる。一方, Yamaguchi ら

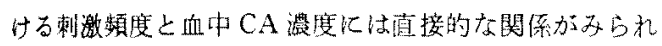
たとして扣り，ある限局した一定の条件下では神経活動 の有力な指標となり得る、臨床面でも特発性起立性低血

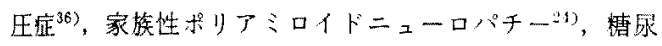
病性二ューロパチー2などの聅慗に批いて活神経本端よ りの分必低下による血中NEの低下が報告されている。 また本態性高血开症の一部では血巾NEの上异が報告さ $れ^{5}$ ，交感神経系の緊張が高血开の成因の一つであう

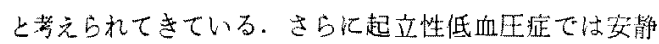
時血中NE值および起立時の血中NE值の增加の有䱏よ り交感神経機能が論じられている方 ${ }^{37}$ 。

一方，血中NEを指標として交感神経機能を論じる場

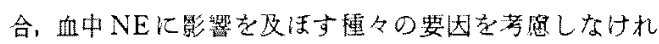

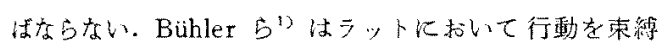
しただけで血中NEが数倍に上䄯することを報告し，㚣 静特の血中NEを求める䟢，ストレスのかからない上う

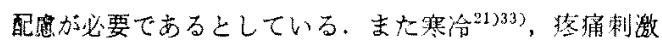

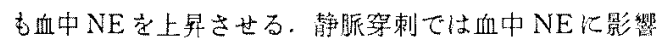
しないとの報告もあるが，全身麻酔下に打ける疼痛刺 激が血中 CA を上算さ世るので，穿刺による䄂痛も程 度の閔題であるう。また嘿煙

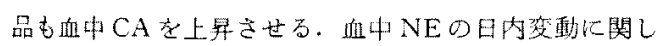
てははっきりしていない加，正常人では日林あまり突

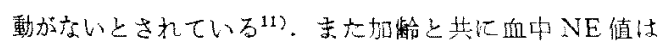
上界するとされている蛙，今回対照上した健康成人の平

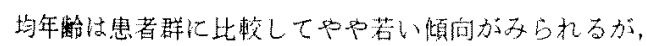

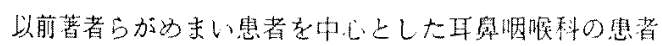

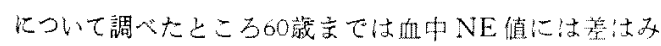

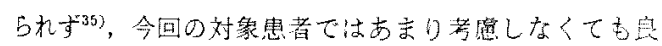

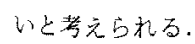

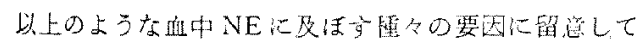

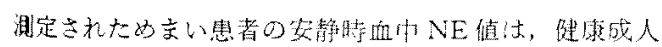

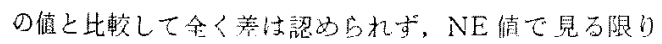

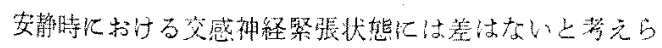
れる。

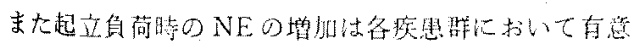

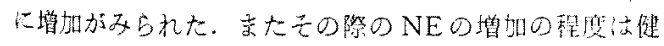

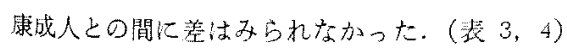

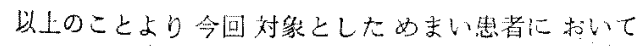

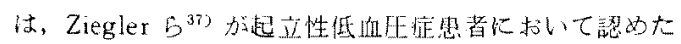

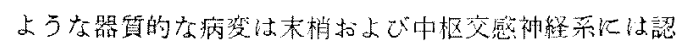
められないであるう上推祭し得る。

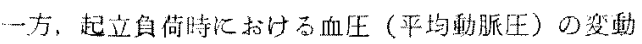

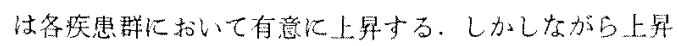

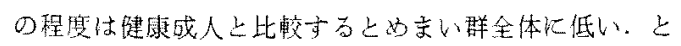
くにメニエール病においてその傾向加箐明である。（表

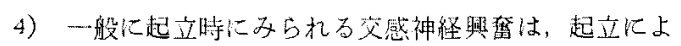

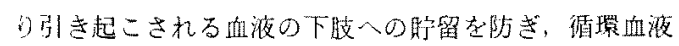
量飞雜持主る機情てあり，その王たる反応的血管收縮及 射であるとされている゙299.起立負荷時に㧍けるNEの分

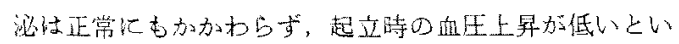

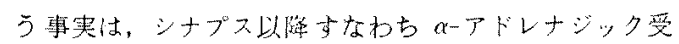

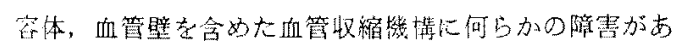
るのではないかと考えすれる。

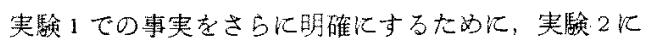
执いてNEを静眽内投与し，血圧八の反応性走检討し

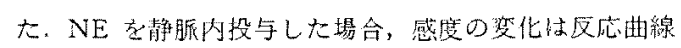
の僙への平行移動，すなわ域值の变化として表わされ る、反底性の変化は反应湶の勾配の变化として表わさ h号 ${ }^{18}$.

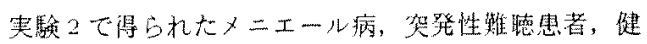
承成人に放ける域值怙よび反応性在比較すると, 城值に おいては患者群と健康成人の間に差は見られない，一方

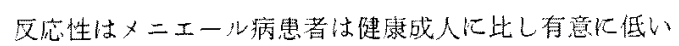

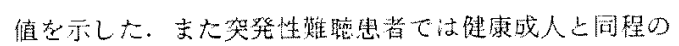
反性を示した。このこ上は起立角荷時の NEの血压に

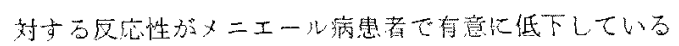

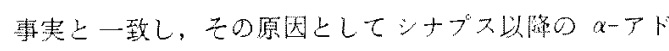

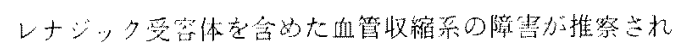
ॐ.

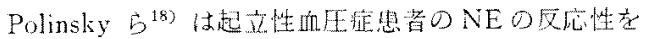

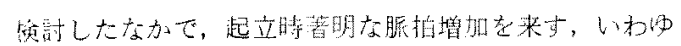

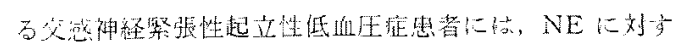

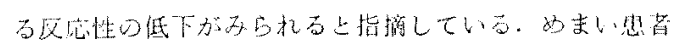

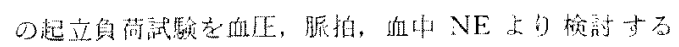

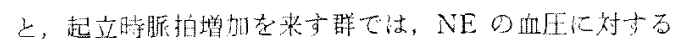

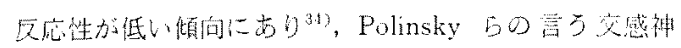

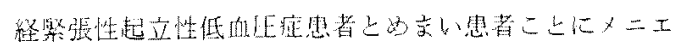

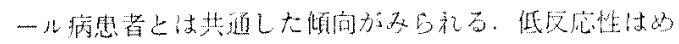

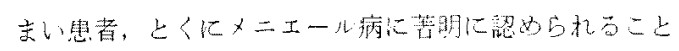

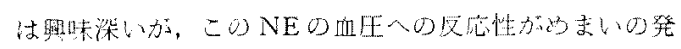

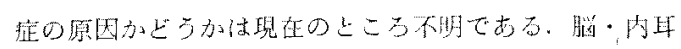




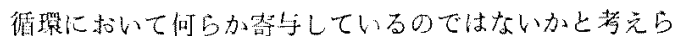

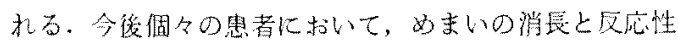
の装化がるれるか，長期的大観然が必要である。

今回報告した变化は全身性の交感神経系の状华であ

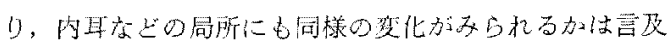
できないが，カテコーラミンに関媇して，メニエール病 䈍者の迷路動脈に私いてアドレナリン作陲性線維の久除 した例が多、年．内耳のメラニン鷹生細胞がNEの分泷

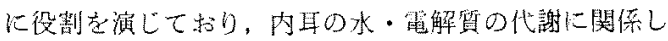

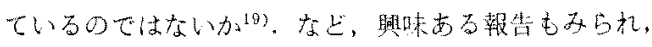
今徭この方面ての梌討も必要である。

\section{V 結 語}

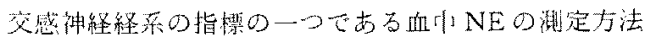

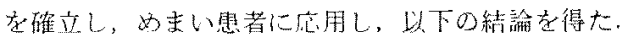

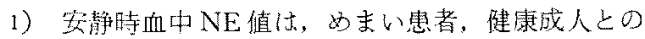
間で差はみられなかった。

2) 起立負荷時血中 NEの尔泌は，めまい患者上健康 成人の間て差は余られなかった。

3）起立負荷時血㺿の上界は健康成人に比しるまい患 者では低い傾向であった。とくにメ二エール病恵者で有 意に㨋明であった。

4） NE静往時にみら机る㨁压入の反店性はメニエー ル病患者では有瑟に低下していた。

5)以上の結果，めまい患者ことにメニエール病患者

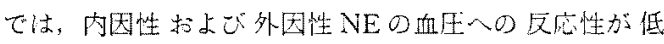

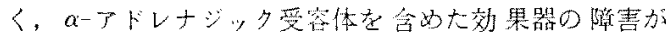
疑われた。

\section{参交執}

1) Buhler H D, Daprada M, Haefely $W$, Picotti G B: Plasma adrenaline, noradrenaline and dopamine in man and different animal species J Physiol 276: 311-320, 1978.

2) Christensen $\mathrm{N} \mathrm{J}$ : Function of small blood vessels and plasma catecholamines in diabetes mellitus. Acta Diabet. Lat 8 (Suppl 1) : 203213, 1971.

3) Cryer $P$ E and Lonis $S$ : Isotope-derivative measurements of plasma norepinephrine and epincphrine in man. Diabetes 25: 1071-1082, 1976.

4) Cryer P E, Haymond M W, Santiago J V, and
Shoh S D: Norepinephrine and epinephrine release and adrenergic mediation of smoking. associated hemodynamic and metabolic events. N Engl J Med 295: 573-577, 1976.

5) Engelman K, Portnoy B and Sjoerdma A: Plasma catecholamine concentrations in patient with hypertension. Circulation Research 27 (Suppl): 141-145, 1970.

6) Gejrot T, Fluur $\mathrm{E}$ and Levi L: Sympathoadrenomedulary activity during experimentally provoked mental stress in patients with labyrinthine defects. Acta Otolaryngol Suppl 224: $260-26 \%, 1967$.

7) Halter J B, Pflug A E and Rorte D Jr: Mechanism of plasma catecholamine increases during surgical stress. J Clin Endocrinol metab 45: 936-944, 1977.

8) Higa S, Suzuki T, Hayasi A, Tsuge I and Yamamura $Y_{:}$Isolation of catecholamine in biological fluids by boric acid gel. Anal Biochem 77: 18-24, 1977.

9) 日前垏介： $x=x 一$ 氏病患者の自律神経機能状熊 に閞する研究 耳然と臨床 6：增3；254-282， 1960.

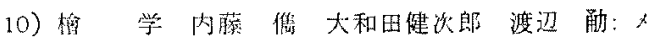
ニエール病 医学甾院 1964.

11) Kato $T$, Hashimoto $Y$ and Nagatsu T: 24-hours rhysm of human plasma noradrenaline and the effect of fusaric acid, a dopamine hydroxylase inhibitor. Neuropsychology 6: 61-65, 1980.

12) Karoum F, Cattabeni F, Costa E, Ruthven CR J and Sanden M: Gas chromatographic assay of picomole concentration of biogenic amines. Anal Biochem 47: 550-561, 1972.

13) Kopin I J, Lake R C and Ziegler M: Plasma levels of norepinephrine. Ann Intern Med 88: $671-680,1978$.

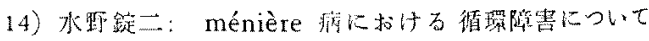
甘耳身 69:2060-2087, 1966.

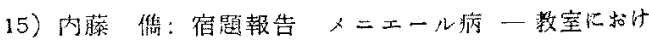

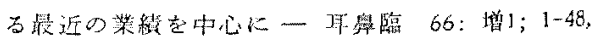
1973.

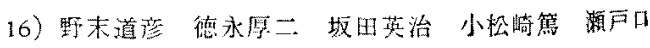




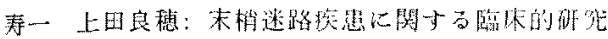
- (そ०2) Mecholyl test, Schellong test, 点状

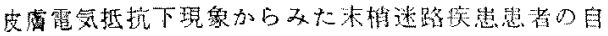
律种程機能 一 耳晚 37：105-114，1955.

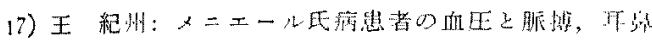
騂 49: 831-833, 1955.

18) Polinsky R J, Kopin I J, Ebert M H and Weise $\mathrm{V}$ : Rharmacologic distinction of different orthostatic hypotension syndrome. Neurology 31: 17, 1981.

19) Rarely K E, Ross M D and Smith C B: Distribution and significance of norepinephrine in the lateral cocholear wall of pigmented and albino rats. Hearing Research 6: 15-23, 1982.

20) Robertson D, Frölich J C, Carr R K, Watson $J T$, Hollifield $J$ W, Shand D G and Oates J A : Effects of caffeine on plasma renin activity, catecholamines and blood pressure. $N$ Engl J Med 298: 181-186, 1978.

21) Robertson D, Johnson D G and Oates J A: Comparative assessment of stimuli that release neuronal and adrenomedullary catecholamines in man. Circulation 59: 637-643, 1979.

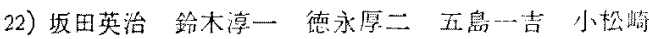

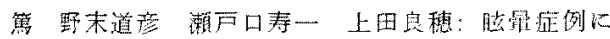

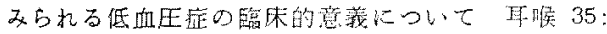
$247-253,1963$.

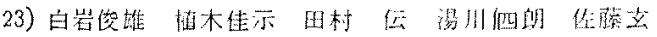

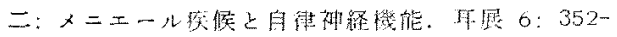
$360,1963$.

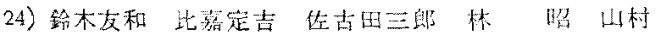

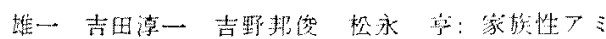

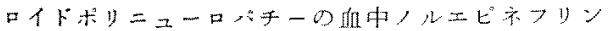
医角又又研究食落 4：183-186，1979.

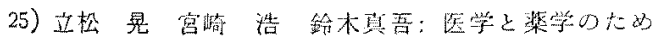
のマススハクトロメトリー 桂社 1975.

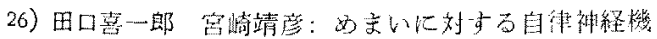

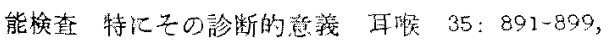
1963.

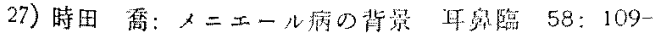
205,1965

28) Torok N: Meniere's syndrome verus Meniere's disease. The Eye, Ear, Nose and Throat
Monthly 37: 770-772, 1958.

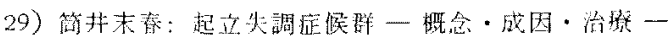
Sandiz Editions for Heath and Care, 1978.

30) Yamaguchi N, De Champlain J and Nadeau R: Correlation between the response of the heart to sympathetic stimulation and release of endogenous catecholamines into the coronary sinus of the dog. Circ Res 36: 662-668, 1975.

31) Ylikoski J, Partnen S and Palva $T$ : Adrenergic innervation of blood vessels. Arch Otolaryngol 105: $726-729,1979$

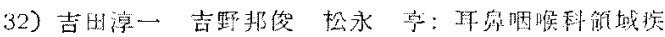

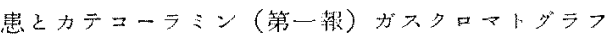

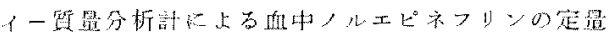
日藏 82: $541-546,1979$ 。

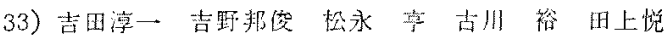
子：ストレスの血中ノルエビネフリンに姑ばす影蝆 耳舆監 73：增 $1 ; 271-278,1980$.

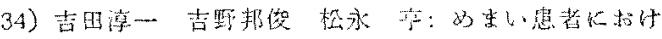

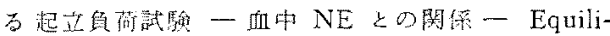
brium Research 39: 244-247, 1980.

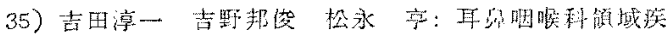

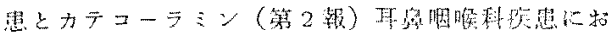

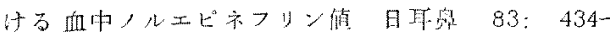
438,1980 .

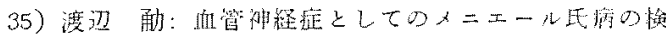
部 $\mathrm{A}+\mathrm{f}$ 58: $338-352,1955$.

37) Ziegler $M G$, Lake $C R$ and Kopin I J: The sympathetic-nervous-system defect in primary orthostatic hypotension. N Engl J Med 296: 293-297, 1977

38) Ziegler $\mathrm{M} \mathrm{G}$, Lake $\mathrm{C}$ R and Kopin I J: Plasma norepinephrine increases with age. Nature 261 $333-335,1976$

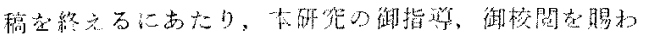

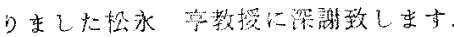

(原街受村 昭和57.11.8日)

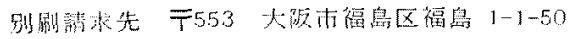

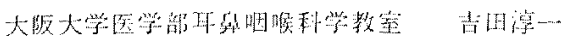

